\title{
Biocatalytic ketone reduction - a study on screening and effect of culture conditions on the reduction of selected ketones
}

\author{
Ramprasad Kuncham ${ }^{1}$, K. T. Gurumurthy ${ }^{2}$, N. Chandan ${ }^{2}$, Aamir Javed $^{2, *}$, \\ L. S. Ashwini ${ }^{2}$, Rahul Shenoi ${ }^{3}$, Anup Baranwal ${ }^{4}$ \\ ${ }^{1}$ Eurofins Genomics India Pvt Ltd. \#183, Gayathri Tech Park, 1st Floor, \\ EPIP 2nd Phase, Whitefield, Bangalore, Karnataka 560066, India. \\ ${ }^{2}$ Shrushti Global Medicare and Research Center, MIG 1/14, KHB Colony, 1st stage, 1st Cross, $60 \mathrm{ft}$ \\ Road, Havanur Circle, Basaveshwarnagar, Bangalore - 5600079 , India \\ *Mob: +91-9916-389-255, +91-9901-383-333, +91-8147-186-910 \\ ${ }^{3}$ Oxford College of Science, Hsr Layout Campus, No.32, 19th Main, 17th 'B' Cross, \\ Sector IV, HSR Layout, Bangalore 560 102, India \\ ${ }^{4}$ Sigma Test and Research Centre, Mangolpuri Industrial Area Phase II, Mangolpuri, \\ New Delhi, DL 110083, India \\ *E-mail address: aamir.javed0077@gmail.com
}

\begin{abstract}
Microbial conversions are gaining importance in the synthesis of important drug metabolites and their intermediates as they are good alternative to chemical synthesis since they are enantioselective and regio-selective and even can be carried out at ambient temperature and atmospheric pressure. Till date, biocatalytic reduction of acetophenone and its derivatives has been widely reported. In the present study, we have made an attempt to carry out the microbial bioreduction of ohydroxyacetophenone by screening some of the selected microorganisms which were obtained from culture collection centre as well as those which are isolated in our Microbiology lab. The selected microorganisms include Aspergillus ochraceous, Aspergillus flavus, Aspergillus tubingenesis, Aspergillus niger, Rhizopus stolanifer MTCC 162, Rhizopus stolanifer MTCC 2591 and Baker's yeast.Among the seven microorganisms screened for the bioreduction of o-hydroxyacetophenone, Baker's yeast and Aspergillus tubingenesis showed significant bioconversion where as Aspergillus ochraceous exhibited the least bioconversion.In our earlier study it was found that Aspergillus flavus has the required bioreductase enzyme, which showed the maximum conversion of $\mathrm{p}$ chloroacetophenone to $\mathrm{p}$-chlorophenylethanol. Hence optimization of culture conditions to get maximum enzyme expression and hence maximum conversion was thought off. The parameters considered for the study include effect of various Carbon sources, Nitrogen source, Metal ions, incubation Temperature and media $\mathrm{pH}$ on enzyme expression. The optimized culture a condition at which maximum bioconversion was achieved was maltose among various carbon sources. Tryptone was found to have maximum effect among the nitrogen sources. Media pH 7.6 and incubation temperature of $35{ }^{\circ} \mathrm{C}$ was found to be favourable for maximum enzyme activity. Among various divalent metal salts, addition of magnesium sulphate to the media significantly increased the enzyme activity.
\end{abstract}

Keywords: Aspergillus ochraceous; Aspergillus flavus; Aspergillus tubingenesis; Aspergillus niger; Rhizopus stolanifer MTCC 162; Rhizopus stolanifer MTCC 2591; Baker's yeast 


\section{INTRODUCTION}

Biotransformation forms the basis of life. Biotransformations are catalyzed by enzymes that are mostly specific for the reaction type and starting compound. Enzyme catalyzes not only the reaction they are evolved for by nature over millions of years, but also the conversion of structurally \& / or electronically similar derivatives. This feature of enzymes can be exploited for numerous technical purposes like cleaning of contaminated environments (bioreduction) or production of high value compounds for chemical, agricultural, \& pharmaceutical industries. Now a days, biocatalysis has become an important alternate for the production of chemicals.

Biotransformations that are presently employed mostly comprises reactions that are catalyzed by microorganisms in terms of growing or resting cells or that are catalyzed by isolated enzymes. Because of high stereo-or regio-selectivity combined with high product purity \& high enantiomeric excesses, biotransformations can be technically superior to traditional chemical reactions. Biocatalysis involves use of natural catalyst, such as enzymes or the whole microbial cells, to perform transformation of organic compounds to their respective products (Kaoru $\mathrm{N}$ et al 2003).

Among the various reactions that are commonly employed in Industry, reduction of carbonyl compounds to respective chiral alcohol is very important as these serve as essential reaction intermediates in various synthetic processes. The asymmetric reduction of ketones is one of the most important fundamental and practical reactions for producing non-racemic chiral alcohols, which can be transformed into various functionalities, without racemization, to synthesize industrially important chemicals such as pharmaceuticals, agrochemicals and natural products.

The catalysts for the asymmetric reduction of ketones can be classified basically into two categories: Chemical and Biological methodologies (Elżbieta P. et al, 2009). Both have their own advantages and disadvantages, and development of both the methods to enable the appropriate selection of the catalysts for particular purposes is necessary to promote green chemistry ${ }^{1}$. There are many chemical reactions which are time consuming, laborious and costly due to high cost of chemical catalysts like Sodium borohydride, lithium aluminium hydride, nickel palladium, zinc etc In contrast the microorganisms have unlimited potential to perform selective biochemical transformations.

The application of microbes to achieve desired functional changes represents one of the most fascinating aspects of man's scientific and technological development. Biocatalytic steps are already in use to produce a wide range of products including agricultural, chemicals, drugs and important commodity chemicals such as acryl amide. These biocatalytic reactions can be carried out in organic solvents or in aqueous media. However, biocatalysis in nonconventional media has shown to be an excellent strategy for organic chemist in the production of chemicals that are difficult to obtain by conventional chemical procedures. The use of enzymes in organic solvents is currently of special relevance for the production of fine chemicals. Nowadays, bulk drugs, and other fine chemicals can be produced by using biocatalysts along with conventional chemical catalysts i.e., chemo-enzymatic synthesis (Magdi A. et al, 2010).

\section{Applications of biotransformation in pharmaceutical field:}

1. The enantioselective hydrolysis of a racemic ester for the formation of (S)-2-ethoxy-3-(4hydroxyphenyl)-propanoic acid, which is used in the synthesis of peroxisomes proliferate activated receptor antagonist (PPARR) and $-c ̧$ agonists. The reaction on the ethyl ester was 
operated on a $44 \mathrm{~kg}$ scale and afforded yields of $43-48 \%$ with ee in the range 98.4-99.6\% (Hanan M. et al, 2011).

2. The synthesis of (R)-2-amino-1-(2-furyl) ethanol using ahuman neutrophil lipocalin (HNL) derived from Hevea brasiliensis, followed by borohydride reduction of the nitrile to the amine. Overall yields were in the 82-95 \% range in repeated runs with an average of $99.7 \%$. Weis and co-workers have described the development, through high-throughput screening, and the use of a recombinant almond $R$-HNL isoenzyme 5 , which is overexpressed in the yeast Pichia pastoris, for the synthesis of $(R)$-cyanohydrins based on natural and unnatural substrates.3. An oxidation reaction that has been scaled up is a catalytic Baeyer- Villiger oxidation of acyclic ketones to lactones using a cyclopentanone monooxygenase from Comamonas NCIMB 9872 supported on a resin (Brahmani Priyadarshini, et al, 2012).

Table 1. Lists the different enzyme classes and their reaction types used for biotransformation that have applications in pharmaceutical, agrochemical, chemical, fragrance \& flavor, nutritional industries.

\begin{tabular}{|c|c|c|c|}
\hline Enzyme class & \multicolumn{2}{|c|}{ Number } & Reaction types \\
\hline & $\begin{array}{c}\text { Classification: EC } \\
\text { Number }\end{array}$ & $\begin{array}{c}\text { Commercially } \\
\text { Available }\end{array}$ & Oxidation/Reduction \\
\hline Oxidoreductase & 650 & 90 & $\begin{array}{c}\text { Complete group } \\
\text { transfer }\end{array}$ \\
\hline Transferase & 720 & 150 & Hydrolysis \\
\hline Hydralases & 636 & 150 & Addition or elimination \\
\hline Lyases & 255 & 35 & Isomerization \\
\hline Isomerases & 120 & 6 & Bond formation \\
\hline Ligases & 80 & 5 &
\end{tabular}

\section{Chirality:}

Molecules that are not superimpossable on their mirror images are chiral. Chirality is necessary and a sufficient condition for the existence of enantiomers. That is to say: a compound whose molecules are chiral can exist as enantiomers; a compound whose molecules are achiral (without chirality) does not exhibit isomerism. The interactions in the body between a drug and the biopolymers, which elicit therapeutic or adverse effects, require a specific three-dimensional configuration of drug and biopolymer. Since enantiomers have different three-dimensional configurations, the pharmacodynamics and pharmacokinetics of the two enantiomers, which make up a racemic drug, can be quite different. The differences often depend on the centre of asymmetry of the drug in close proximity to the points of attachment to the biopolymer (Aguilaret, al, 2003).

For e.g.

- (S)-Ibuprofen is over 100-fold more potent inhibitor of cyclo-oxygenase I than (R)Ibuprofen.

- (R)-methadone has a 20-fold affinity for the A $\mu$ opioid receptor than (S)-methadone 
The inactive enantiomer or distomer is not necessarily an inert substance with no effects in vivo. For eg, the cardiotoxicity of bupivacaine is mainly associated with the (R)enantiomer, the psychomimetic effects of ketamine are more associated with the (R)enantiomer, and (S)-baclofen antagonises the effects of (R)-baclofen. The beneficial effects of a drug can therefore reside in one enantiomer (eutomer), with its paired enantiomer having:

- No activity eg. (S)-Eszopiclone, an oral sedative drug is responsible for the desired activity whereas (R) form is inactive.

- Some activity eg. Ibuprofen, a racemic mixture of two enantiomers, (+)-(S)ibuprofen and (-)-(R)-ibuprofen in which majority of the effects are elicited by $(+)-(\mathrm{S})$-ibuprofen.

- Antagonist activity against the active enantiomer eg. Salbutamol whose bronchodialator activity resides with (S)-salbutamol whereas (R)-salbutamol have proinflammatory effects.

- Separate therapeutic response or adverse activity from the active enantiomer eg. R-fluoxetine is useful for depression while S-fluoxetine is envisaged for migraine treatment.

\section{Advantages of biocatalysis over chemical synthesis:}

$>$ Biocatalytic reactions are often highly enantioselective and regioselective. They make selective differentiation between enantiomeric substrates.

$>$ They can be carried out at ambient temperature and atmospheric pressure, thus avoiding the use of extreme conditions that can cause problems with isomerization, racemization, epimerization and rearrangement reactions.

$>$ Microbial cells and enzymes derived from them can be immobilized and reused for many cycles.

$>$ Very large enzymes can act as multi enzyme complexes and can be useful for multiple reactions. Thus it can be a valuable tool in the production of series of compounds.

$>$ Enzymes can be over-expressed to make biocatalytic processes economically efficient, and enzymes with modified activity can be tailor made.

$>$ Preparation of thermostable and $\mathrm{pH}$ stable enzymes by random and site directed mutagenesis has led to the production of novel biocatalysts.

\section{Drawbacks of biocatalysis:}

There are three essential drawbacks for the use of biocatalysts:

$>$ Biocatalysts are often not sufficiently stable in the desired media. Enzymes are deactivated under a range of conditions such as extremes of temperature or $\mathrm{pH}$ value, physical forces such as cavitations by pumps and aqueous-organic or gas- liquid interfaces or by specific covalent interactions.

$>$ Too few biocatalysts exist for the desired reactions for available substrates to get targeted products. This is mainly due to the usage of multi enzyme complexes.

$>$ Development cycles are too long for new and improved biocatalysts. The development of some biocatalytic processes takes between 10 and 20 years For example, development of the acrylamide process took 20 years. So shortening the development cycle time for a particular biocatalyst should therefore be a topic of active research. 


\section{Biocatalytic reduction of ketones:}

Chiral alcohols are very useful materials in the specialty chemical and pharmaceutical industries. Enantiomerically pure alcohols are valuable chiral building blocks for industrial fine chemicals (Xiao, et al, 2011). For example, these compounds act as key intermediates in the production of pharmaceuticals, fine chemicals and natural products. Some examples of pharmaceuticals with chiral alcohols as intermediates include antihypertensive drugs, Calcium and Potassium channel blocking drugs, antiarrhythmic agents, $\beta_{3}$-receptor agonists, anticholesterol and antiviral drugs. The interconversion of a ketone to the corresponding chiral alcohol and vice versa represents one of the most common redox-reactions in organic chemistry. Traditional synthetic methods predominantly use toxic metals and expensive complex hydrides in the synthesis of alcohols. Biotransformations on the other hand offer some significant advantages. Various chiral alcohols can be produced by biocatalysis using two methods: kinetic resolution of the racemic starting material or direct synthesis- from a prochiral compounds (Chiu-yeh, et al, 2011).

\section{Concept of biocatalytic reduction:}

The enzymes employed in redox reactions can be classified into three categories:

Dehydrogenases, oxygenases and oxidases. Among them, dehydrogenases have been widely used for the reduction of carbonyl carbons of aldehydes or ketones and of carbon-carbon double bonds (Kyoungkeun, et al, 2004).

Since reduction generates a stereogenic center, the desymmetrization of prochirals carbonyl compounds is predominant. Redox reactions require redox cofactors which donate or accept the chemical equivalents for reduction. For majority of redox enzymes, Nicotinamide adenine dinucleotide [NAD $(\mathrm{H})]$ and its respective phosphate [NADP $(\mathrm{H})]$ are required as cofactors. Reduction with $\mathrm{NADH}$ is as follows:

1. Co-enzymes and substrate bind to the enzyme.

2. The substrate is reduced, while the co-enzyme gets oxidized.

3. The co-enzyme and product dissociate from the enzyme.

The detailed study of the reaction mechanism of NAD (P) H dependent dehydrogenase explains that there are four stereochemical patterns for transfer of a hydride from co-enzyme, NAD (P) H, to substrate. As shown in Fig 1 with E1 and E2 enzymes, the hydride attacks the $s i$-face of the carbonyl group, whereas with E3 and E4 enzymes, the hydride attacks the reface, which results in the formation of $(R)$ and $(S)$-alcohols, respectively. On the other hand, E1 and E3 enzymes transfer the pro- $(R)$-hydride of the coenzyme, and E2 and E4 enzymes use the pro- $(S)$-hydride. Thus the hydride attacks either side-face or re-face of the carbonyl group depending on the orientation of the binding of the substrate to the enzyme, which results in the formation of $(\mathrm{R})$ and $(\mathrm{S})$ alcohols respectively. On the other hand, enzyme transfers either pro-(R) or pro-(S) of the co-enzyme depending on the kind of enzyme, Fig. 1. 


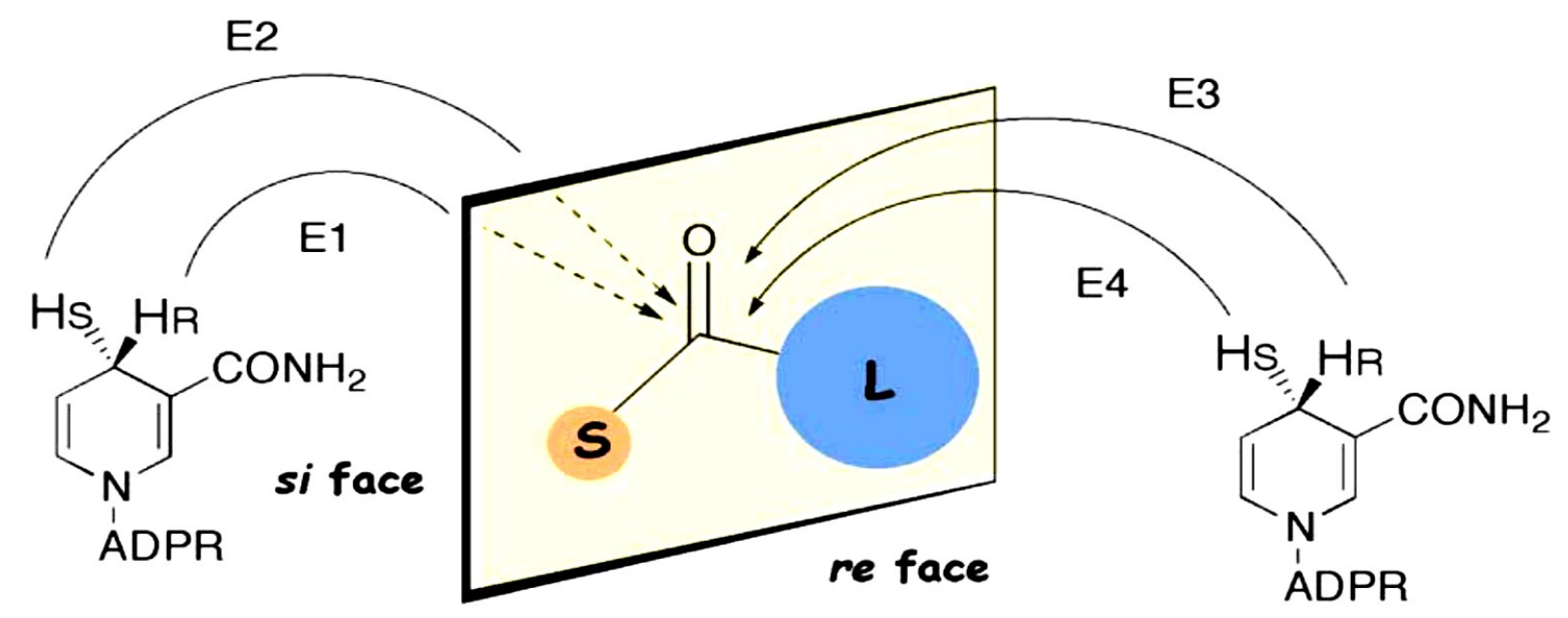

(E1, E2, E3, E4 are different kinds of enzymes)

Fig. 1. Reaction mechanism of NAD (P) H dependent dehydrogenase.

\section{Biotransformation process:}

Biotransformation can be performed by using either isolated enzymes or whole cells of microorganisms in free / immobilized form. The method employed will depend on the

1. Type of the reaction.

2. Requirement of cofactors.

3. Scale of biocatalysis.

\section{Reactions with whole cells:}

The advantages which are related in using whole cells are that expensive co-factors are not required. It is suited for multistep process requiring several enzymes. This process is cost effective as compared to pure enzymes as it requires inexpensive co substrates. The whole cell systems are more stable compared to pure enzymes as they are not easily affected by the environmental factors.

The disadvantages associated with this system is that the substrate may undergo more than one biochemical reaction as whole cell contains a complete metabolic compliment of enzymes resulting in low product yield. Product purification is complicated in this method due to presence of other metabolic by-products, cell components and cell growth media components.

Further in this process maintenance of aseptic condition is critical as biological contamination may interfere with the product yield. Even the semi permeable nature of cell may complicate substrate entry and/ or product release from the cell. In recent years, the usefulness of recombinant strains of fission yeast Schizosaccharomyces pombe that express human P450 for the production of P450 metabolites of illicit drugs and doping substances was shown, eventhough it contains certain drawbacks.

On adding the substrate to the microbial culture, first the substrate should cross the cell membrane and then reach the enzymatic system for conversion. To overcome these problems, many other modifications in biotransformation process have been developed for whole cell biotransformation (Neelakantam et al 2005). 


\section{Biotransformation using immobilized whole cells:}

Whole cell immobilization can be defined as the physical confinement or localization of intact cells to a certain defined region of space with the preservation of some desired activity. The principal methods for whole cell immobilization are adsorption, covalent binding, encapsulation, entrapment and crosslinking. There are various methods and classifications of cell immobilisation where natural and synthetic materials as suitable immobilisation matrices have been studied. One method of cell immobilisation is microencapsulation, where spherical beads of immobilised cells are formed The usage of immobilized cells in biotransformation offers many advantages such as increased chemical and mechanical stability with whole cell immobilization.

\section{Reactions with free enzymes:}

The advantages of using free enzymes are that it results in high activity with better yield. Pure enzyme catalyses only a specific reaction and therefore there is no risk of byproducts or product breakdown. In this process downstream processing of the product is easier as compared to whole cell system as there are no interference of by-products and cell components (Sivakumar T., et al., 2012).

\section{Biotransformation process in growing culture:}

In this method, the substrate is added to the fermentation medium at the time of inoculation or during a later phase of microbial growth. Later it is incubated until maximum yield of transformation has been reached. The principle behind this method is that the expression of required enzyme for the desired biotransformation may be enhanced by induction, if the substrate is added during active growth of microorganism. The process is suitable for inducible enzymes (Sukumar M., et al., 2010).

\section{Biotransformation process in resting cells:}

This method involves cultivation of microorganisms under conditions optimum for maximum growth, the actual biotransformation being performed in a second step. This method is applicable where substrates inhibit cell growth and the enzyme involved in the conversion is constitutive enzymes, production of which does not get affected by the chemical environment (Zi-Jun X., et al., 2009).

\section{Reduction of aldehydes and ketones using whole cells:}

Since isolated dehydogenases require sophisticated cofactor recycling, whole microbial cells can be employed for this purpose. They contain multiple dehydogenases which are able to accept non-natural substrates, all the necessary cofactors and the metabolic pathways for their regeneration. Thus, cofactor recycling can be omitted, since it is automatically done by the cell. As a consequence, cheap carbon sources such as glucose or saccharose can be used as auxillary substrates for asymmetric reduction reactions.

\section{Biocatalysis in Industry:}

For the past 10 years or so, many fine chemical companies have been exploring the use of biocatalytic processes in the synthesis of their products or for the custom synthesis of particular client-defined compounds. Frequently, these studies have been driven by a regulatory need, as far as pharmaceutical entities are concerned, to incorporate chiral centers 
in drugs and drug candidates. As a result, a number of classes of enzymes have evolved, including hydrolases, oxidoreductases, transferases, lyases, ligases and isomerases to effect selected organic transformations. The ability to induce chirality in a molecule through synthesis has also been examined for several reaction processes. An example would be the enantioselective hydrolysis of a racemic ester as described for the formation of $(S)$-2-ethoxy3-(4-hydroxyphenyl)-propanoic acid, which is used in the synthesis of PPAR $\gamma($ peroxisomesproliferate activated receptory antagonist) and $\gamma$-agonists. The reaction on the ethyl ester was operated on a $44 \mathrm{~kg}$ scale and afforded yields of $43-48 \%$ with ee in the range 98.4-99.6\%

\section{Media Optimization:}

The basic nutrients for the growth of microorganisms include carbon, nitrogen and minerals. Incubation period has also a great effect on the mass production. It was found that the effect of different factors affecting microbial growth such as incubation period, temperature, $\mathrm{pH}$, aeration, addition of surfactants, the constituents of the growth medium used especially carbon sources, nitrogen sources and minerals depends greatly on microbial strain and its growth rate. Any medium for microbial growth should contain minimum, specific elements in the appropriate proportions for maximum growth. Once a media is developed the next phase is to optimize the media composition to achieve best possible results (Augusto J et al 2004).

\section{Effect of media composition on bioreduction:}

There has been various research activities directed towards evaluating the effect of different carbon and nitrogen sources as well as presence of various divalent metal ions in the media on the yield of enzymes. Each organism or strain has its own special conditions for maximum enzyme production.

\section{Effect of media composition on production of enzymes:}

Effect of Carbon Source: The cell wall of fungi determines the cell shape and integrity of the organism during growth and cell division. Three main groups of polysaccharides form the cell wall: polymers of mannose (mannoproteins - $40 \%$ of the cell dry mass), polymers of glucose (b-glucan - $60 \%$ of the cell wall dry mass) and polymers of $\mathrm{N}$-acetylglucosamine (chitin - $2 \%$ of the cell wall dry mass). b-Glucan can be divided into two subtypes following the mode of glucose linkages: long chains of ca $1500 \mathrm{~b}$-1,3-glucose units which represents $85 \%$ of total cell wall b-glucan, and short chain of $150 \mathrm{~b}$-1,6-glucose units that accounts for $15 \%$ of the b-glucan. The cell wall is a dynamic structure that can adapt to physiological and morphological changes (Hiromichi $\mathrm{O}$ et al 2001)

a) Effect of Nitrogen source: Source of nitrogen is one of the important factor that affect the growth and metabolites of microorganisms. Variation in the nitrogen source can affect the metabolic processes of the cell significantly ${ }^{9}$. Various nitrogen sources that can be used in the media are peptone, beef extract, yeast extract, tryptone, malt extract, keramine, yeast peptone powder, bactopeptone, ammonium sulphate, hydrolysed vegetable protein etc.

b) Effect of Metal ions: The presence of metal ions in the culture media greatly affects the metabolic activity of the microbial cell. The metal ions act as co-factors in various enzymatic reactions. They are important regulators of enzyme production. Various metal 
ions that can be used in the media are zinc sulphate, copper sulphate, calcium chloride, ferric chloride, magnesium sulphate, chromium ion etc.

c) Effect of pH: It is a well known fact that $\mathrm{pH}$ plays an important role in the bioreduction as the variation in $\mathrm{pH}$ will alter the ionic state of substrate and enzymes involved in the reaction. The optimum $\mathrm{pH}$ for growth of fungi usually falls in the acidic range.

d) Effect of Temperature: The reaction temperature is one of the most important factors affecting the catalytic characteristics of a biocatalyst. The incubation temperatures of the microbial cells affect some of its metabolic activities.

\section{Need of study:}

Microorganisms and enzymes are employed for the transformation of synthetic chemicals in a highly chemo-regio and enantioselective manner. Chiral intermediates are in high demand for pharmaceutical, agriculture and other biotechnological industries for the preparation of bulk drug substances or fine chemicals. The enantioselective reduction of ketones to obtain optically active alcohols, has gained importance, as they are important building blocks for the production of most of the pharmaceuticals (Adi W., et al, 2001).

Often, so-called blockbuster drugs that are marketed with sales in the billion US\$ range, are based on these chiral alcohol moiety. Thus, there are numerous efficient asymmetric catalytic routes based on various concepts from the field of kinetic resolution to asymmetric synthesis, which has been developed upto date.

Without any doubt, outstanding technologies in the latter field are the metal catalysed assymetric hydrogenation of the ketones and the borne reduction.

Both technologies, which can be regarded as the landmark in industrial asymmetric catalysis in general, are applied widely on technical scale and certainly represents the benchmark for any other type of alternative catalytic reduction methodology.

\section{OBJECTIVE OF STUDY}

I. The main objective of the present study was to screen potential microorganisms for the reduction of o-hydroxyacetophenone. Varied range of fungi, obtained both from collection counter and locally isolated species were used for bioreduction.

1. Microorganisms selected for bioreduction:

- Rhizopus stolonifer MTCC 162.

- Rhizopus stolonifer MTCC 2591.

- Aspergillus flavus (soil isolate)

- Aspergillus ochraceous (soil isolate)

- Aspergillus tubingenis ( soil isolate)

- Aspergillus niger (soil isolate)

- Baker'syeast 
2. Substrate for bioreduction: O-hydroxyacetophenone.

3. Biotransformation of prochiral ketone to corresponding alcohol.

4. Spectral characterization and quantification of the product.

II. Effect of compositions of culture media on bioreduction of p-chloroacetophenone with Aspergillus flavus as maxium reduction of p-chloroacetophenone was shown by Aspergillus flavus in our earlier study, Carbon source, Nitrogen source, Metal ion, Incubation Temperature \& Media PH.

\section{METHODOLOGY}

\section{Materials and methods}

II. Equipment and Supplies

- Ultrasonicator.

- UV spectrophotomer.

\section{Chemicals}

i. NADH $(4.5 \mathrm{mM})-2.98$ gms of NADH was dissolved in $1000 \mathrm{ml}$ of distilled water.

ii. p-chloroacetophenone $(10 \mathrm{mM})-1.546 \mathrm{gms}$ of $\mathrm{p}$-chloroacetophenone was dissolved in $1000 \mathrm{ml}$ of DMSO.

\section{1. Microorganisms}

A) Aspergillus niger, Aspergillus flavus, Aspergillus ochraceous, Aspergillus tubingenegis(soil isolate) and two strains of Rhizopus stolonifer MTCC 162 and MTCC 2591:

The organisms were isolated in the microbiology department of DSI and identified at Bangalore University. These organisms were maintained on MRBA media.

B) Saccharomyces cerevisaeMTCC 174, Candida viswanathii MTCC 1629

The organisms were obtained from MTCC Chandigarh and maintained in microbiology lab. These organisms were maintained on YEPD media.

\section{2. Baker's yeast was purchased locally}

\section{2. 1. Cultivation of Microorganisms}

Cultivation of Aspergillus niger, Aspergillus flavus, Aspergillus ochraceous, Aspergillus tubingenesis

The spore from maintaince culture was inoculated into $100 \times 20 \mathrm{ml}$ of potato dextrose medium containing potato $200.0 \mathrm{~g}$, dextrose $5.0 \mathrm{~g}$ and distilled water $1000 \mathrm{ml}$. The $\mathrm{pH}$ of the medium was adjusted to 6.0. The medium was sterilized at $121{ }^{\circ} \mathrm{C}$ for $15 \mathrm{mins}$. The inoculated medium was incubated at $25^{\circ} \mathrm{C}$ for 7 days to get sufficient biomass. The mycelial biomass was separated by filtration and washed with phosphate buffer twice (Zhong-Hua Y., et al, 2008). 


\section{Cultivation of Rhizopus stolonifer, Saccharomyces cerevisae, Candida viswanathii}

The spore from maintaince culture was inoculated into 100x20 $\mathrm{ml}$ of potato dextrose medium. The $\mathrm{pH}$ of the medium was adjusted to 6.0 . The medium was sterilized at $121^{\circ} \mathrm{C}$ for 15 mins. The inoculated medium was incubated at $25^{\circ} \mathrm{C}$ for 7 days to get sufficient biomass. The mycelial biomass was separated by filtration and washed with phosphate buffer twice.

\section{2. 2. Chemical reduction of ortho-hydroxy acetophenone}

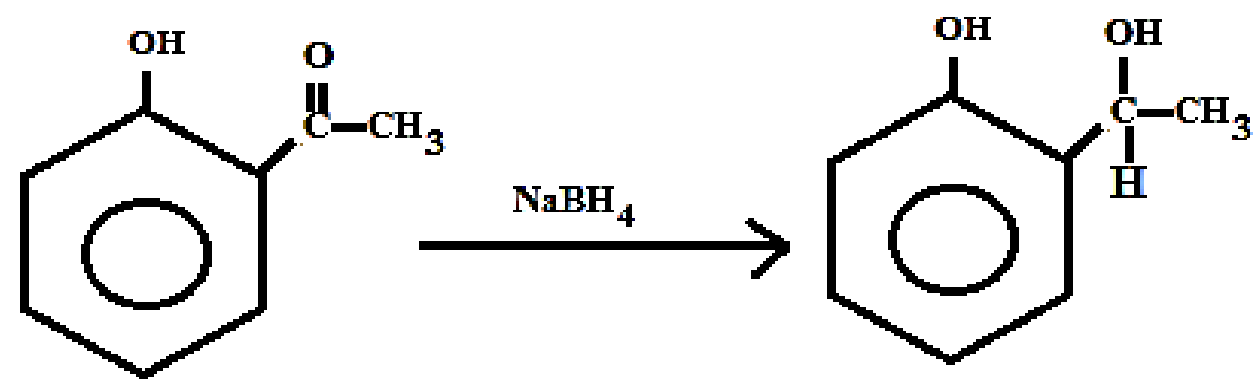

ortho-hydroxy acetophenone

ortho-hydroxyphenylethanol

The substrate was chemically reduced by using sodium borohydride.

\section{Experimental procedure:}

About $1 \mathrm{ml}$ of ortho-hydroxyacetophenone was dissolved in $20 \mathrm{ml}$ of ethanol. The solution was stirred with a glass rod while in an ice-bath and $1.0 \mathrm{~g}$ of sodium borohydride was added in small portions to the cold solution over 5 mins. The solution was stirred for 15 mins using a magnetic stirrer. It was then transferred to $100 \mathrm{ml}$ beaker, $30 \mathrm{ml}$ of water was added and the volume was reduced to about $30 \mathrm{ml}$ by evaporation. The solution was then cooled to room temperature and was transferred to a separating funnel and extracted thrice with $20 \mathrm{ml}$ of dichloromethane.

The combined dichloromethane extract was washed with $20 \mathrm{ml}$ brine solution twice and dried over anhydrous sodium sulphate. The dried dichloromethane extract was later evaporated to get the reduced product. The product formation was confirmed by TLC using ethyl acetate: hexane: acetic acid (5:4:1) solvent system (S. R. Brahmani, et al, 2012). The reduction of the substrate was confirmed by IR spectral analysis. This product was used as the standard for comparison with the microbially reduced product.

\section{Chromatogram of O-Hydroxyacetophenone (Fig. 4-10)}

The product formation was confirmed by TLC using ethyl acetate: hexane: acetic acid (5:4:1) solvent system (S.R. Brahmani, et al, 2012).

The reduction of the substrate was confirmed by IR spectral analysis. This product was used as the standard for comparison with the microbially reduced product. 


\section{Part A}

\section{3. Bioreduction of ortho-hydroxyacetophenone (Fig. 2):}

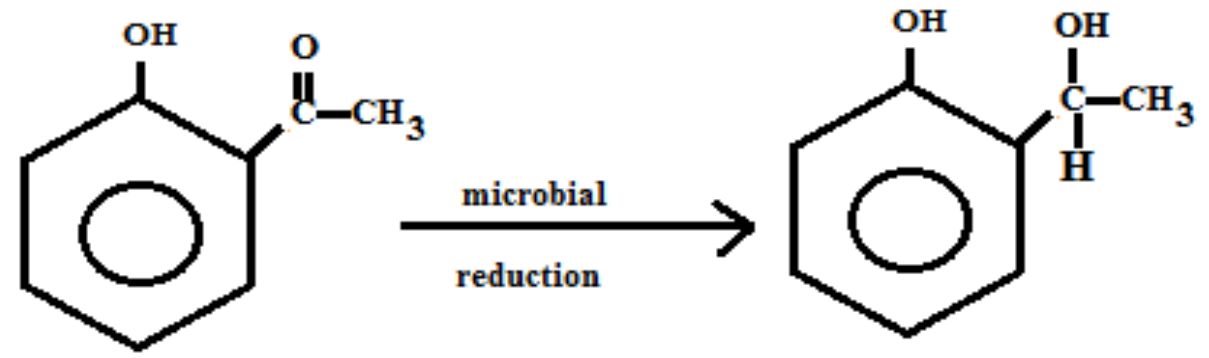

ortho-hydroxyacetophenone

ortho-hydroxyphenylethanol

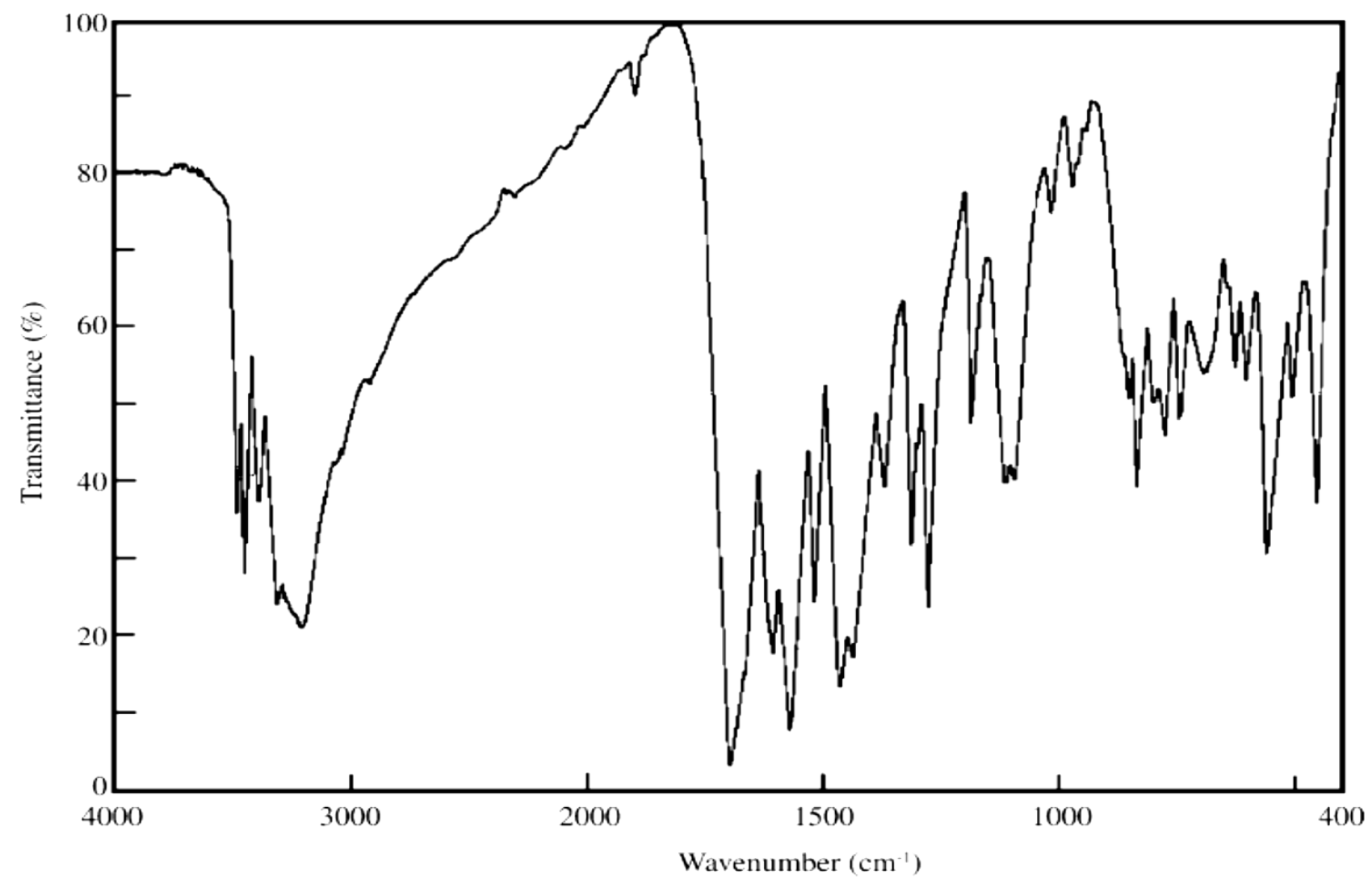

Fig. 2. IR spectra of o-hydroxyacetophenone reactant.

\section{3. 1. Bioreduction with Aspergillus niger, Aspergillus flavus, Aspergillus ochraceous and two strains of Rhizopus stolonifer MTCC162 and 2591}

\section{Experimental procedure:}

About $50 \mathrm{mg}$ of ortho-hydroxyacetophenone and $5 \mathrm{~g}$ of the wet biomass was taken in a $250 \mathrm{ml}$ conical flask, $20 \mathrm{ml}$ of phosphate buffer of $\mathrm{pH} 7.6$ and $2.5 \mathrm{~g}$ of glucose was added to the reaction mixture and the resulting mixture was incubated at $30{ }^{\circ} \mathrm{C}, 160-\mathrm{rev} \mathrm{min}^{-1}$ for 48 
hrs (Yang G., Shanjing Z., et al, 2009). The cells were separated by filtration. The filtrate was extracted thrice with $20 \mathrm{ml}$ of dichloromethane. The combined extracts was then washed with $20 \mathrm{ml}$ of brine solution twice, dried over anhydrous sodium sulphate and evaporated to get the residue. The product formation was confirmed by TLC using ethyl acetate: hexane: acetic acid $(5: 4: 1)$ solvent system.

\section{3. 2. Bioreduction with Baker's yeast, Aspergillus tubingenesis, Saccharomyces Cerevisae, Candida viswanathii:}

\section{Experimental procedure (Fig. 3):}

About $50 \mathrm{mg}$ of ortho-hydroxyacetophenone \& $5 \mathrm{~g}$ of the biomass was taken in a 250 $\mathrm{ml}$ conical flask, $20 \mathrm{ml}$ of phosphate buffer $\mathrm{pH} 7.6$ and $2.5 \mathrm{~g}$ of glucose was added to the reaction mixture and the resulting reaction mixture was incubated at $30^{\circ} \mathrm{C}, 160-\mathrm{rev} \mathrm{min}^{-1}$ for $48 \mathrm{hrs}$. The cells were separated by filtration using buchner funnel and the biomass was washed with phosphate buffer twice. The filtrate was extracted thrice with dichloromethane. The combined extract was then washed with $20 \mathrm{ml}$ of brine solution twice, dried over anhydrous sodium sulphate and evaporated to get the residue. The product formation was confirmed by TLC using ethyl acetate: hexane: acetic acid $(5: 4: 1)$ solvent system (Zhang J. et al, 2007). The product was quantified by HPLC analysis.

\section{HPLC ANALYSIS}

\section{1. Methodology}

The mobile phase consisted of acetonitrile and water (1:1 ratio). The mobile phase was filtered through $0.45 \mu$ by membrane filter.

\section{1. 1. Chromatographic conditions}

$\begin{array}{lll}\text { Column } & : & \mathrm{C} 18 \text { phenomenex } 250 \times 4.6 \mathrm{~mm}, 0.5 \mu \mathrm{m} \\ \text { Flow rate } & : & 1 \mathrm{ml} / \mathrm{min} . \\ \text { Wave length } & : & 215 \mathrm{~nm} \\ \text { Injection volume } & : & 20 \mu \mathrm{l} .\end{array}$

\section{2. Preparation of standard graph of ortho-hydroxyphenylethanol}

Figure 3, IR spectra of product o-hydroxyphenylethanol.

\section{2. 1. Procedure}

\section{A) Preparation of standard stock solution}

About $40 \mathrm{mg}$ of chemically reduced product was accurately weighed and transferred into a clean, dry $50 \mathrm{ml}$ volumetric flask and dissolved in small quantity of methanol (HPLC grade). The volume was made upto $50 \mathrm{ml}$ mark, which gave a concentration of $0.8 \mathrm{mg} / \mathrm{ml}$ or $800 \mu \mathrm{g} / \mathrm{ml}$. This solution was kept as standard stock solution A.

\section{B) Preparation of working standard solution}

From the standard stock solution A, $6.25 \mathrm{ml}$ was pippeted out into $50 \mathrm{ml}$ volumetric flask and the volume was made upto $50 \mathrm{ml}$ which gave a concentration of $100 \mu \mathrm{g} / \mathrm{ml}$. from 
this solution, aliquotes of $1 \mathrm{ml}, 2 \mathrm{ml}, 3 \mathrm{ml}, 4 \mathrm{ml}, 5 \mathrm{ml}$, were pippeted into $10 \mathrm{ml}$ volumetric flasks. The volume was made up with methanol (HPLC grade) upto the mark. This gave the working solution with a concentration of $10 \mu \mathrm{g} / \mathrm{ml}, 20 \mu \mathrm{g} / \mathrm{ml}, 30 \mu \mathrm{g} / \mathrm{ml}, 40 \mu \mathrm{g} / \mathrm{ml}$ and 50 $\mu \mathrm{g} / \mathrm{ml}$ respectively (Chanakya P., et al. 2010).

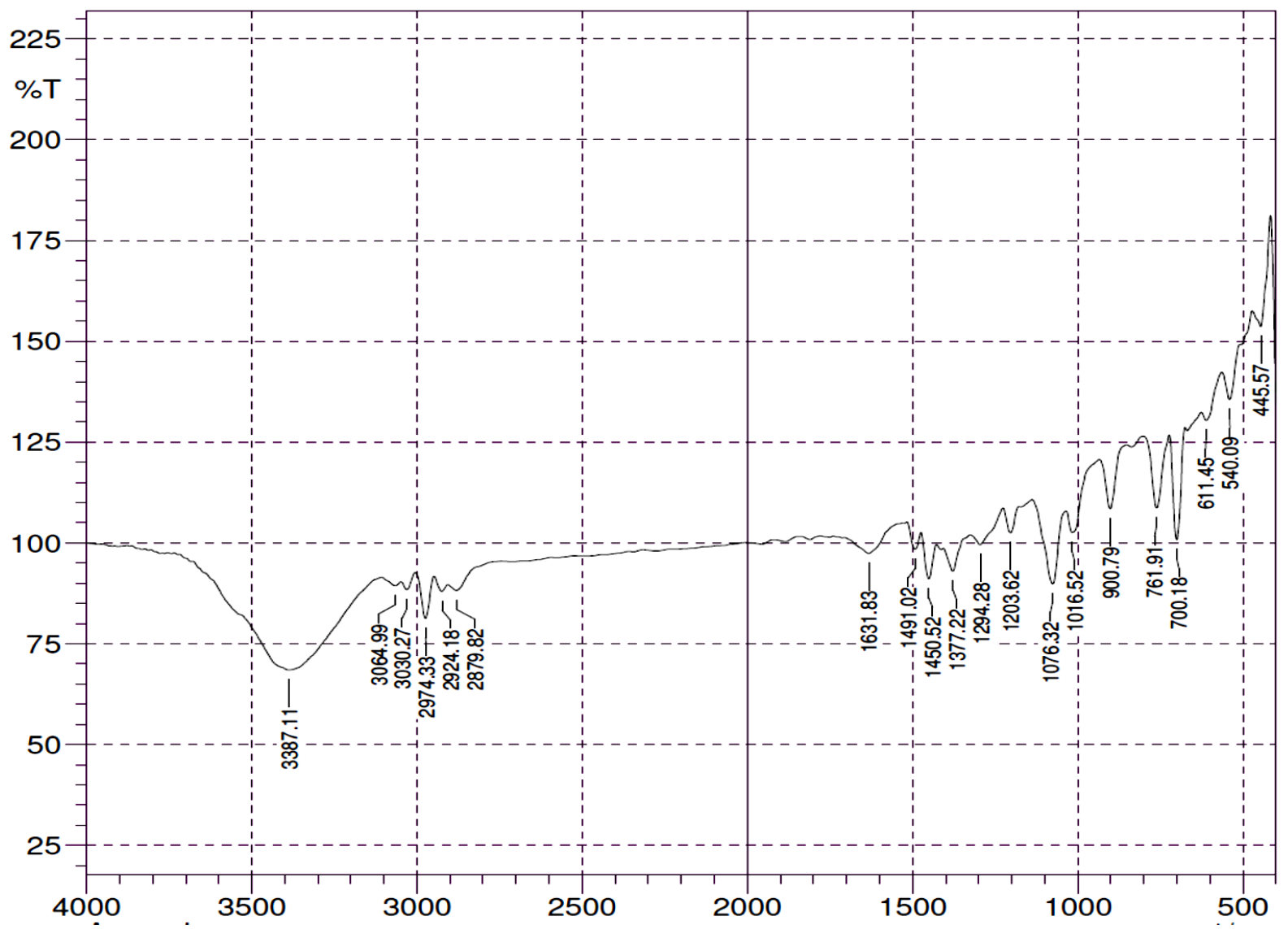

Fig. 3. IR spectra of product o-hydroxyphenylethanol.

\section{C) Sample preparation}

The sample obtained was lyophilized and diluted to $10 \mathrm{ml}$ with methanol (HPLC grade) and injected.

\section{Part B}

4. 3. Study on the effect of media constituents on enzyme activity as Aspergillus flavus showed maximum conversion of p-chloroacetophenone in our earlier study, the effect of media constituents on the production of dehydrogenase enzyme responsible for the reduction of ketone was taken up for further study. 


\section{3. 1. Materials and methods:}

\section{Chemicals:}

P-chloroacetophenone was used as the substrate for media optimization for reductase enzyme.

Microorganisms:

Aspergillus flavus was selected for the optimization experiment as it gave considerable conversion of the substrate.

\section{3. 2. Methodology:}

\section{Inoculum preparation:}

The organism was maintained in MRBA media and then the spores from the maintaince culture was inoculated onto potato dextrose media containing potato $200 \mathrm{~g}$, dextrose $5 \mathrm{~g}$ and distilled water $1000 \mathrm{ml}$ incubated at $25^{\circ} \mathrm{C}$ for 5 days (Rekha $\mathrm{K}$ et al 2006).

\section{Shake flask experiment:}

The effect of various carbon source, nitrogen source, metal ions, temperature and $\mathrm{pH}$ on the enzyme activity was studied by innoculating $2 \mathrm{ml}$ of the innoculum to each of $50 \mathrm{ml}$ of different media.

\section{3. 3. Procedure for the cultivation in different media: Effect of different carbon sources on enzyme activity:}

Six different carbohydrates glucose, mannitol, maltose, sucrose, lactose and glycerol were used in six different PDB media. $2 \%$ of six different carbohydrates were added to six $250 \mathrm{ml}$ conical flask containing $50 \mathrm{ml}$ of PDB media, $\mathrm{pH}$ was adjusted to 6 and sterilized for 15 mins at $121^{\circ} \mathrm{C} .2 \mathrm{ml}$ of the innoculum containing Aspergillus flavus was innoculated and incubated for 5 days at $160 \mathrm{rev} \mathrm{min}^{-1}$ at room temperature (Vahap Y., et al., 2006). The biomass was separated by filtration and the mycellium was harvested by standard procedure to get crude enzyme extract.

\section{Effect of different nitrogen sources on enzyme activity:}

Five different organic sources of nitrogen peptone, malt extract, yeast extract, tryptone and beef extract were used in five different PDB media. $2 \%$ of five different nitrogen sources were added to five $250 \mathrm{ml}$ conical flask containing $50 \mathrm{ml}$ of PDB media, $\mathrm{pH}$ was adjusted to 6 and sterilized for 15 mins at $121^{\circ} \mathrm{C}$. $2 \mathrm{ml}$ of the innoculum containing Aspergillus flavus was innoculated and incubated for 5 days at $160 \mathrm{rev} \mathrm{min}^{-1}$ at room temperature. The biomass was separated by filtration and the mycellium was harvested by standard procedure to get crude enzyme extract

\section{Effect of different metal ions on enzyme activity:}

Five different metal ion sources zinc sulphate, copper sulphate, calcium chloride, ferric chloride and magnesium sulphate were used in five different PDB media. $2 \mathrm{mM}$ of five different metal ion sources were added to five $250 \mathrm{ml}$ conical flask containing $50 \mathrm{ml}$ of PDB media, $\mathrm{pH}$ was adjusted to 6 and sterilized for $15 \mathrm{mins}$ at $121^{\circ} \mathrm{C} .2 \mathrm{ml}$ of the innoculum

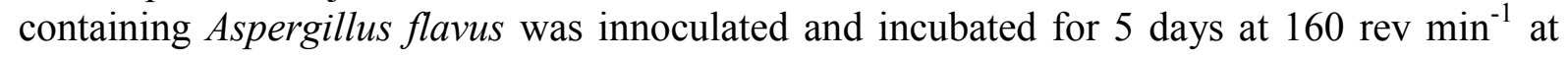
room temperature. 


\section{Effect of media pH on enzyme activity:}

To five different $250 \mathrm{ml}$ conical flask containing $50 \mathrm{ml}$ of PDB media $2 \mathrm{ml}$ of innoculum containing Aspergillus flavus was innoculated maintaining five different $\mathrm{pH}$ range $6.4,6.8,7.2,7.6$ and 8. The reaction mixture was incubated for 5 days at $160 \mathrm{rev} \mathrm{min}^{-1}$ at room temperature.

\section{Effect of different temperature on enzyme activity:}

To five different $250 \mathrm{ml}$ conical flask containing $50 \mathrm{ml}$ of PDB media, $2 \mathrm{ml}$ of inoculum containing Aspergillus flavus was inoculated and incubated at five different temperature keeping media $\mathrm{pH}$ constant at 6 . The reaction mixture was incubated for 5 days at $160 \mathrm{rev}^{\mathrm{min}}{ }^{-1}$ at $25^{\circ} \mathrm{C}, 30^{\circ} \mathrm{C}, 35^{\circ} \mathrm{C}$ and $40^{\circ} \mathrm{C}$.

\section{Crude enzyme extract:}

The mycellium was harvested by filtration and washed with distilled water. The harvested mycellium was pressed in between filter papers and kept in freezer. The frozen mass was subjected to ultrasonication in cold condition. The cell debris were removed by centrifugation at $20,000 \mathrm{rpm}$ for $1 \mathrm{hr}$ at $4{ }^{\circ} \mathrm{C}$. The supernatant was used for activity measurement. Reductase activity was determined spectrophotometrically by measuring the decrease in the absorbance of NADH at $340 \mathrm{~nm}$ (Vijayalakshmi, et al., 2011).

The reaction mixture contained $4 \mathrm{ml}$ of cell free extract, $20 \mu 1$ of NADH $(4.5 \mathrm{mM})$ and, $20 \mu \mathrm{l}$ of p-chloroacetophenone (10 mM DMSO). Ketone reduction was followed over a time period of 5 mins. One unit of enzyme activity is defined as the amount of enzyme required to oxidise $1 \mu 1$ of NADH to NAD per minute.

Amount of product formed $\propto \Delta \mathrm{AU}$ (change in absorbance units):

$\Delta \mathrm{AU}=\Delta \mathrm{A} \times$ vol of assay reaction

$=\mathrm{x} / \mathrm{min} \mathrm{x} 4.0 \mathrm{~mL}=\mathrm{y} \mathrm{AU} / \mathrm{min}$ for $100 \mu \mathrm{L}$ enzyme

To convert absorbance units (AU) to mmol product divide $\mathrm{AU} / \mathrm{a}_{\mathrm{M}}$ :

$$
\begin{aligned}
& =\frac{\mathrm{yAU} / \mathrm{min}}{6220}=\mathrm{z} \times 10^{-5} \mathrm{mmol} / \mathrm{min} \\
& =\mathrm{z} \times 10^{-2} \mu \mathrm{mol} / \mathrm{min}
\end{aligned}
$$

NOTE: $\mathrm{a}_{\mathrm{M}}$ for NADH is 6220

\section{RESULTS AND DISCUSSION}

Enantiopure drugs are in great demand and hence developing new techniques to obtain the same has become a necessity in organic synthesis.Enantioselective reduction of ketones represents a straight forward and an economical approach towards production of optically active alcohols which are important building blocks in the synthesis of many pharmaceuticals Bioreduction of acetophenone and its derivatives has been extensively reported in literature. In our present work, we have made an attempt to screen some of the selected fungi for the 
bioreduction of ortho-hydroxyacetophenone which have not been reported earlier. Totally seven different fungi were selected for the study. They were:

Rhizopus stolonifer MTCC 162, Rhizopus stolonifer MTCC 2591, Aspergillus flavus (soil isolate) Aspergillus ochraceous (soil isolate),Aspergillus tubingenis ( soil isolate), Aspergillus niger (soil isolate), Baker's yeast.

The bioreduction process was carried out in two stages.

1. Cultivation of selected microorganisms in the specified culture media to obtain sufficient biomass.

2. Reduction of ketone using biomass.

In the screening it was found that Aspergillus species and Baker's yeast were capable of bringing out the reduction of o-hydroxyacetophenone. This indicated that the fungi had the required oxido reductase enzyme which accepted the xenobiotic substrate. Out of the five fungi, Baker's yeast and aspergillus tubingenesis showed the maximum conversion while Aspergillus ochraceous showed the least conversion.

\section{1. Study of effect of culture conditions on enzyme activity:}

In our earlier study it was found that Aspergillus flavus has the required bioreductase enzyme, which showed the maximum conversion of p-chloroacetophenone. Hence optimization of culture conditions to get maximum enzyme expression and hence maximum conversion was thought of. It is also known that the media constituents have a great impact on enzyme expression. Therefore a study was done to analyze the effect of various carbon and nitrogen sources, metal ions, change in media $\mathrm{pH}$ and incubation temperature on enzyme activity.

The synthesis of enzymes by microorganisms has been reported to be highly influenced by factors such as carbon sources, nitrogen sources and other various operating parameters like $\mathrm{pH}$ and temperature. Study of effect of carbon and nitrogen sources has been of great importance commercially for designing low cost media. As Aspergillus flavus showed the maximum conversion of $\mathrm{p}$-chloroacetophenone, it was selected for optimization of culture conditions. The parameters evaluated include: Carbon source, Nitrogen source, Metal ions, Temperature \& $\mathrm{pH}$.

\section{a) Effect of Carbon source:}

Six different carbohydrates (glucose, mannitol, maltose, sucrose, lactose and glycerol) were used in six different media and the results were tabulated. From the table it is clear that maltose (disaccharide) is the preferred carbon source by the selected organism for the production of enzyme, followed by glucose, which are simple sugars. Dissacharide sugar like lactose and sucrose showed less effect. There has been reports of studies by E.Mahmoud and M.H Alla (2001) on the production of siderophores by some microorganisms where it was found that glucose proved to be the most suitable carbon source for Pseudomonas aeurginosa, Aspergillus nidulans and Penicillium chrysogenum whereas Bradyrhizobium japonicum gave its highest yield when grown on mannitol.

\section{b) Effect of Nitrogen source:}

The effect of five different organic sources of nitrogen was studied. The addition of organic nitrogen did not have positive effect on enzyme production. Significant difference was not seen in the enzyme activity with different nitrogen sources. Among the different 
nitrogen sources used, tryptone showed maximum effect compared to other nitrogenous compounds. Enzyme expression depends on different nitrogen sources as well as on the nature of microorganisms and this has been reported in various articles.

\section{c) Effect of Metal ions:}

The effect of some divalent metal ions were studied. The observation showed that addition of Magnesium sulphate to the media enhanced the bioreduction of $\mathrm{p}$ chloroacetophenone by Aspergillus flavus whereas addition of calcium chloride had the least effect. Each organism or strain has its own special conditions for maximum enzyme production.

\section{d) Effect of pH:}

The effect of media $\mathrm{pH}$ ranging from 6.4 to 8 on the enzyme induction was studied. The optimum $\mathrm{pH}$ for the growth of fungi usually falls in the acidic range but maximum enzyme activity was found at $\mathrm{pH}$ 7.6. There is no significant difference in enzyme activity in acidic $\mathrm{pH}$ but in basic $\mathrm{pH}$ enzyme activity is increased. While optimizing $\mathrm{pH}$ parameter, it was found that $\mathrm{pH} 7.6$ was optimum for the bio-reduction of the substrate indicating the specific dehydrogenase is more active in alkaline medium.

\section{e) Effect of Temperature:}

The cells grown at different temperatures did not show any marked difference in the activity of the enzyme. The maximum enzyme activity was observed at $30{ }^{\circ} \mathrm{C}$ and least activity was seen at $40{ }^{\circ} \mathrm{C}$. There has been reports of studies done by Soni P., Kansal H. (2010) on optimization of process parameters for the production of carbonyl reductase by Candida viswanathii in a laboratory-scale fermentor which states that a maximum carbonyl reductase activity was attained at $25^{\circ} \mathrm{C}$.

\section{SUMMARY AND CONCLUSIONS}

Bioreduction of o-hydroxyacetophenone was carried out using seven different strains of fungi i.e Baker's yeast, Rhizopus stolonifer MTCC 162, Rhizopus stolonifer MTCC 2591, Aspergillus flavus, Aspergillus ochraceous, Aspergillus tubingenis and Aspergillus niger (soil isolate) which were obtained both from collection center and locally isolated species.

Out of seven microorganisms screened for bioreduction, only five of the selected strains exhibited ketone reduction capability. Aspergillus species were found to be more efficient in reduction of ketones. Maximum reduction was observed with Baker's yeast and Aspergillus tubingenesis while the least bioreduction was found with Aspergillus ochraceous.

The following observations were made from the study on optimising the various media composition and culture conditions for bioreduction of p-chloroacetophenone with Aspergillus flavus, as maximum reduction was shown by Aspergillus flavus. Among the various carbon sources used in the study, maltose in the culture media affected enzyme activity significantly.

Tryptone was found to have maximum effect among the various nitrogen sources tested for enzyme production. It was found that nitrogen sources did not contribute significantly to the production of reductase enzyme. 
When culture media $\mathrm{pH}$ and incubation temperatures were varied to know the effect of these parameters on enzyme activity, Media $\mathrm{pH} 7.6$ and incubation temperature of $35^{\circ} \mathrm{C}$ was found to have maximum effect on enzyme activity. While in the study of effect of various divalent metal salts on enzyme activity, it was observed that the magnesium sulphate in media had significant effect on the enzyme activity.

Further works can be pursued to improve the yield of the reduced product by altering the other parameters like:

By optimizing various reaction parameters like

1. Temperature.

2. $\mathrm{pH}$.

3. Biomass concentration.

4. Mmedia components.

5. Incubation time.

6. Substrate concentration etc.,

\section{Tables and Graphs:}

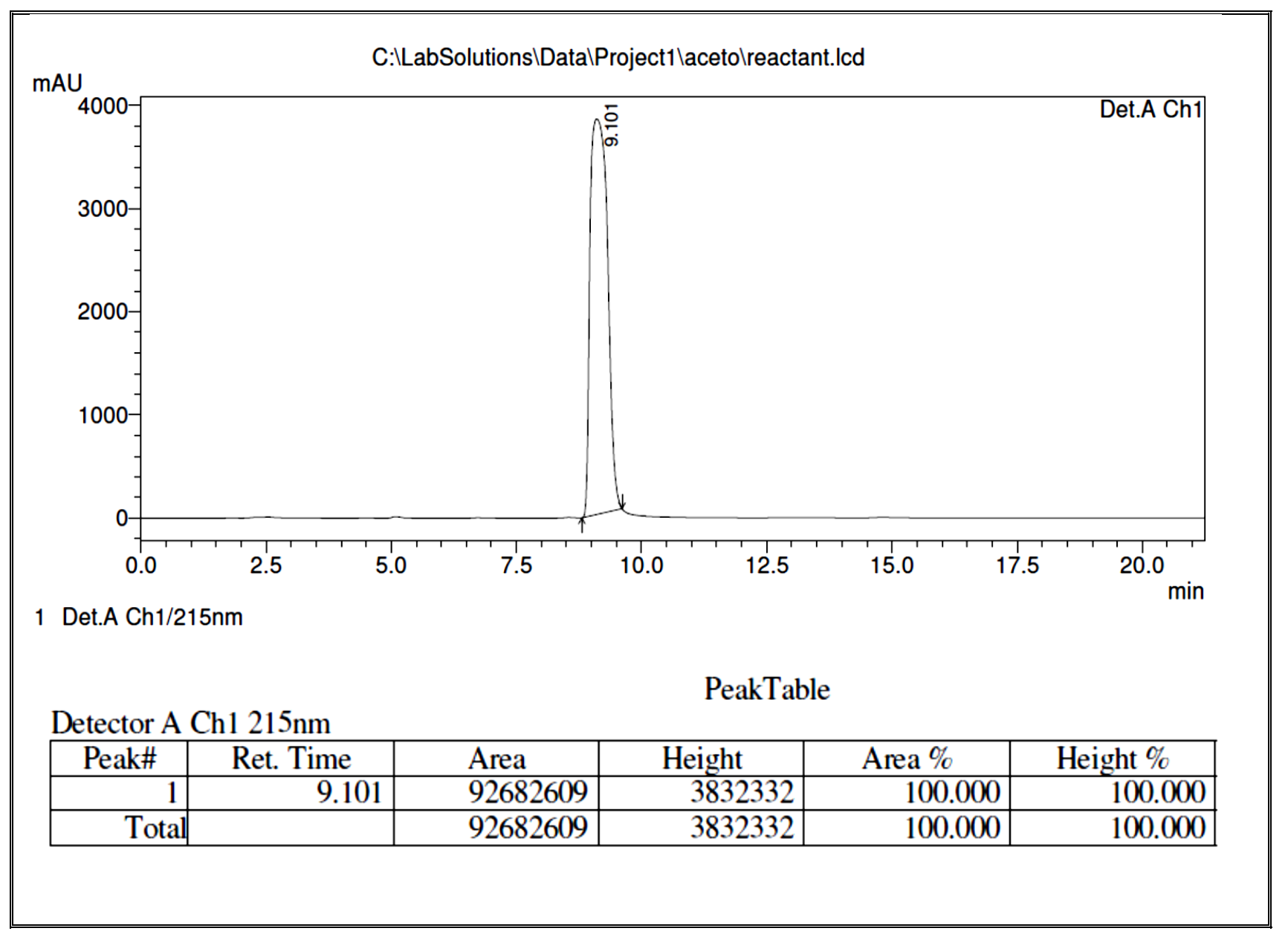

Figure 4. Chromatogram of o-hydroxyacetophenone reactant. 


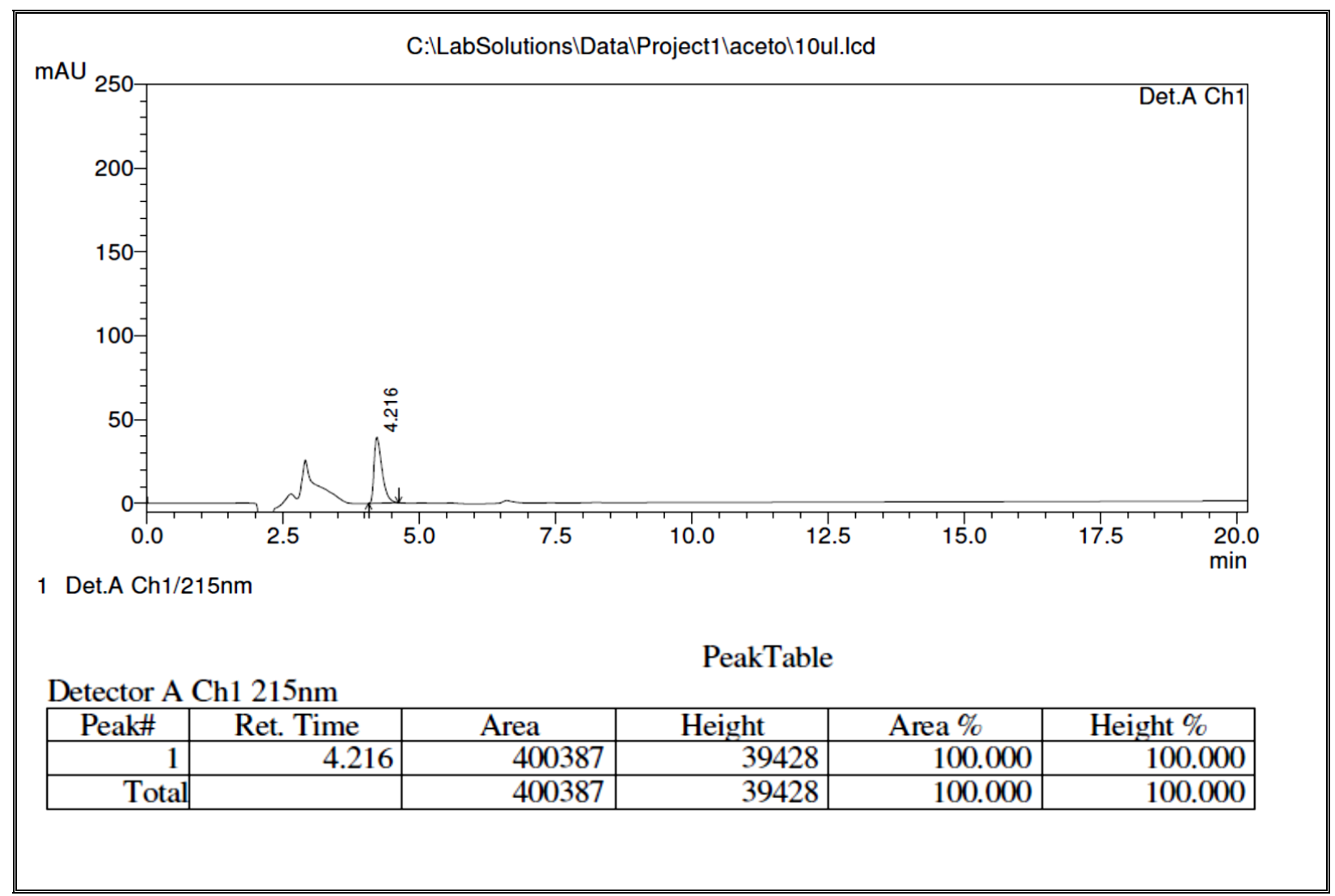

Figure 5. Chromatogram of standard product o-hydroxyacetophenone $(10 \mu \mathrm{g} / \mathrm{ml})$.

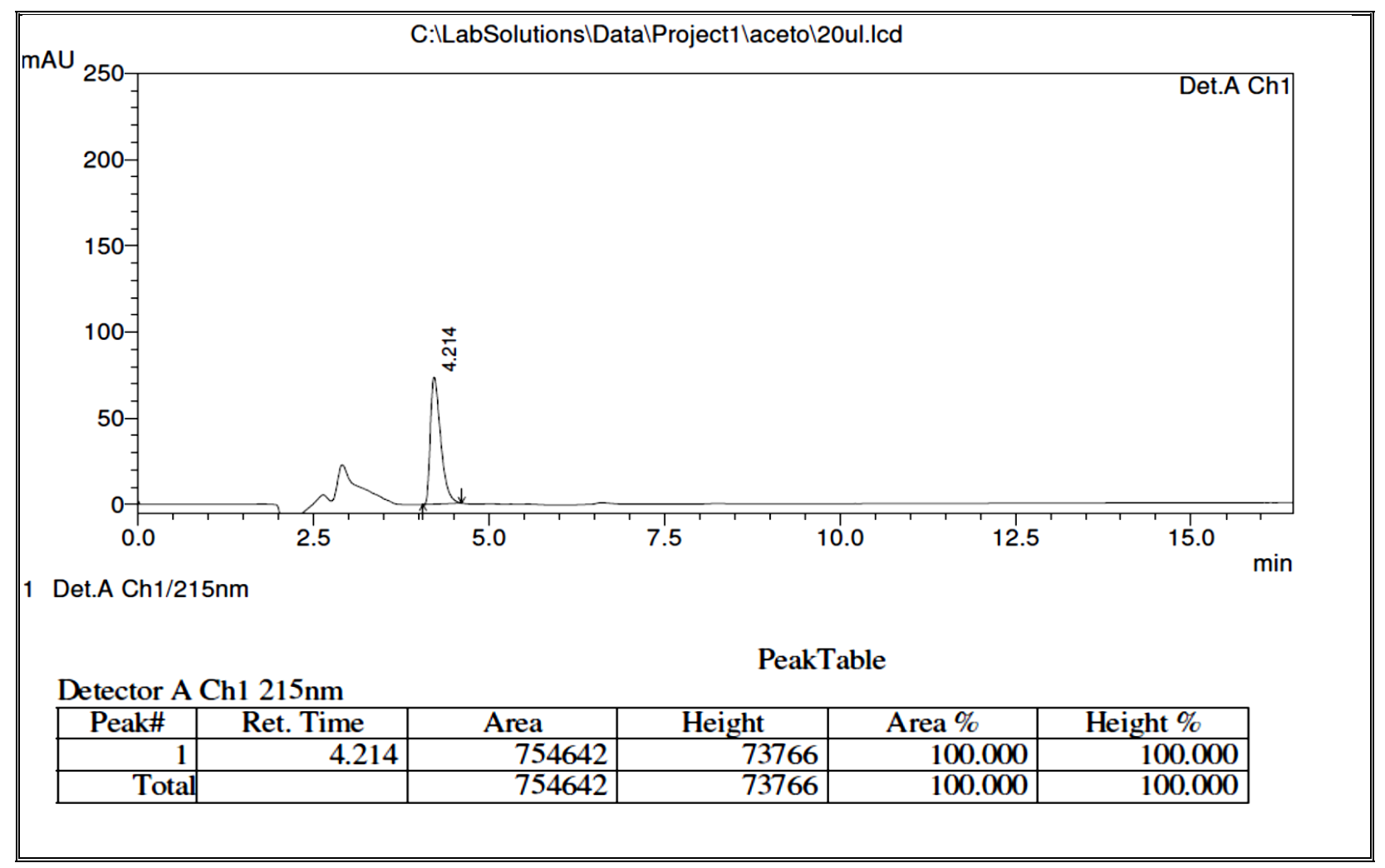

Figure 6. Chromatogram of standard product o-hydroxyacetophenone $(20 \mu \mathrm{g} / \mathrm{ml})$. 


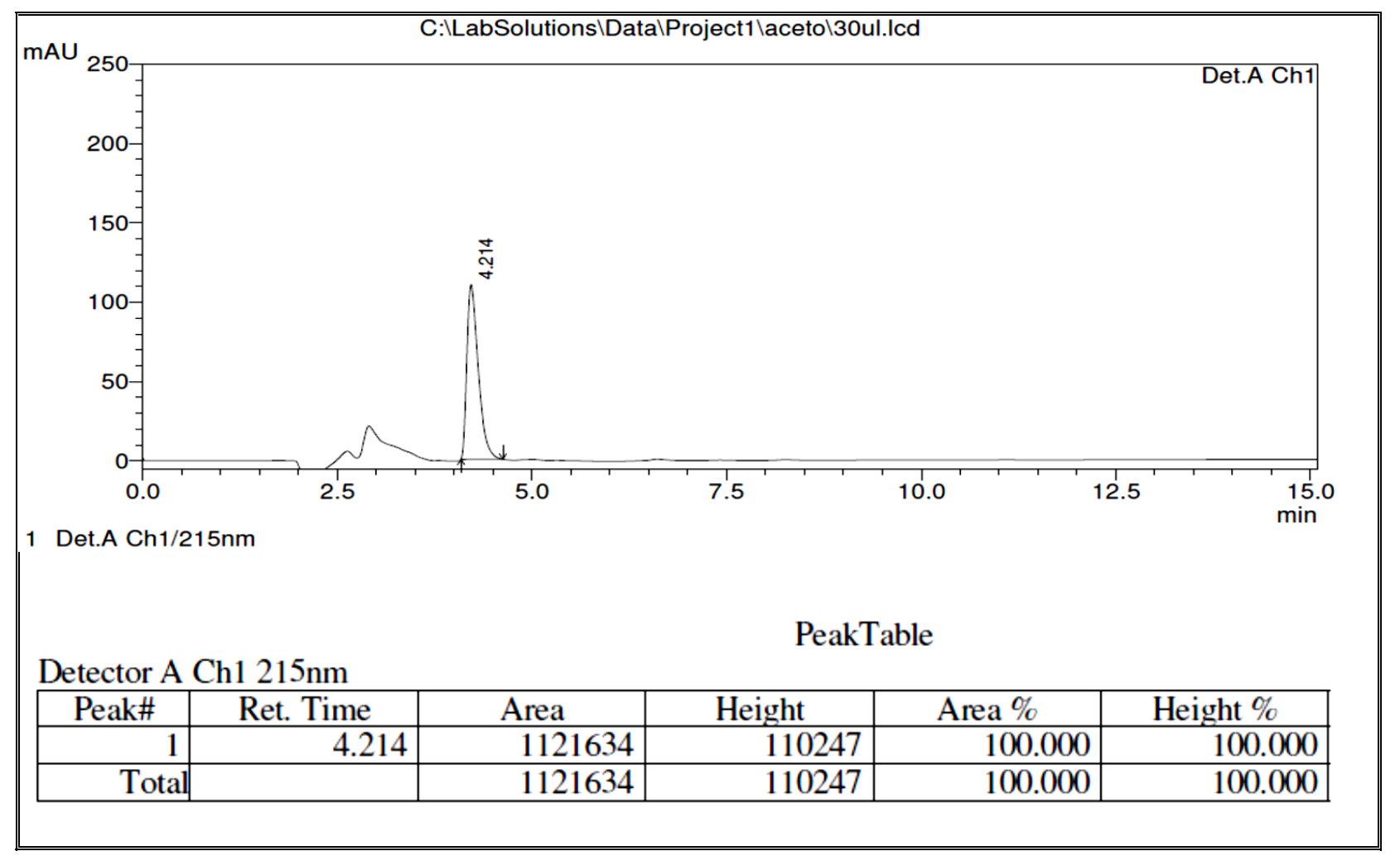

Figure 7. Chromatogram of standard product o-hydroxyacetophenone $(30 \mu \mathrm{g} / \mathrm{ml})$.

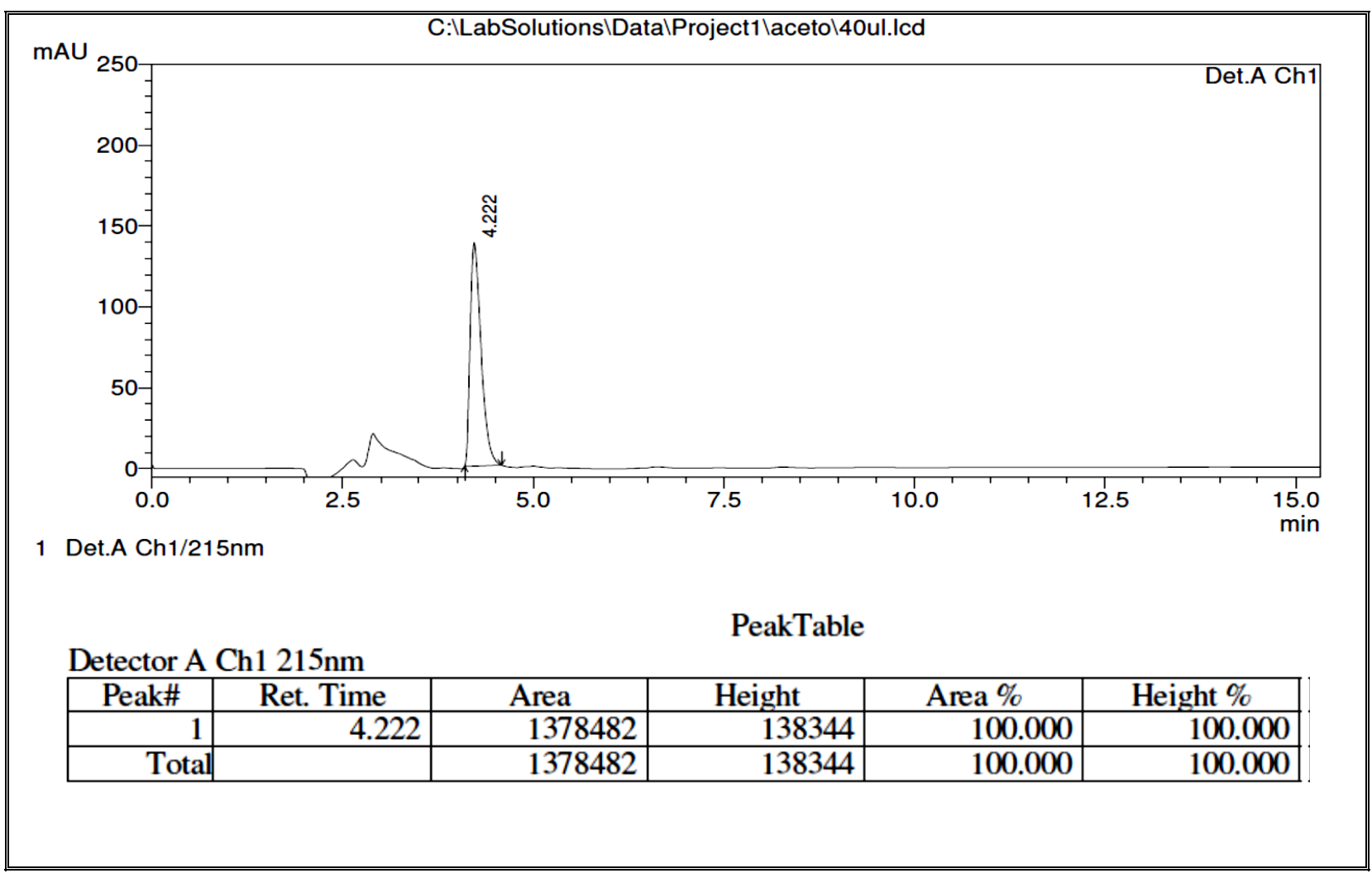

Figure 8. Chromatogram of standard product o-hydroxyacetophenone $(40 \mu \mathrm{g} / \mathrm{ml})$. 


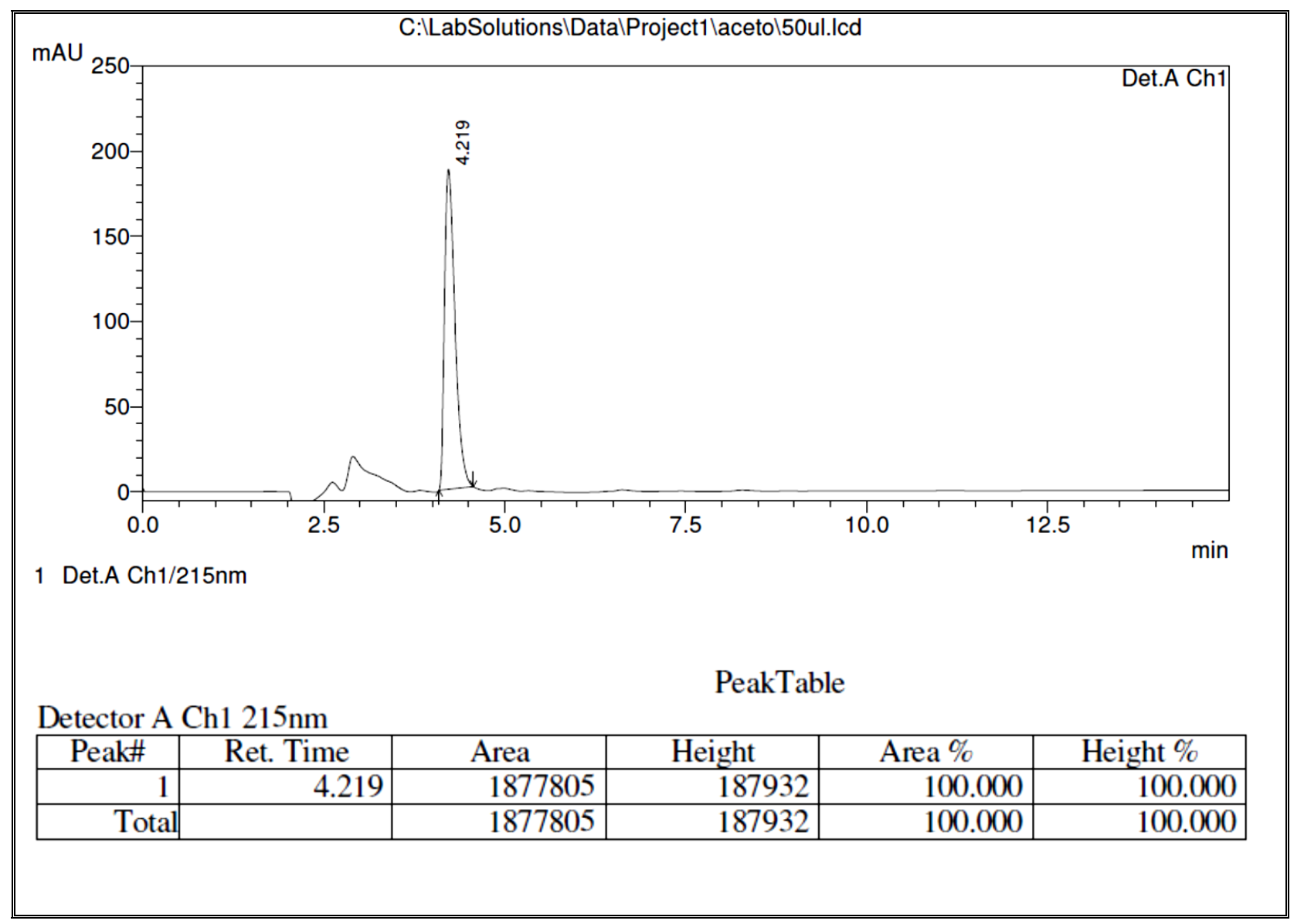

Figure 9. Chromatogram of standard product o-hydroxyacetophenone $(50 \mu \mathrm{g} / \mathrm{ml})$.

\section{Preparation of standard graph of product o-hydroxyphenylethanol:}

The standard graph of o-hydroxyphenylethanol was plotted using substrate concentration vs. AUC.

Table 2. Preparation of standard graph of product o-hydroxyphenylethanol.

\begin{tabular}{|c|c|}
\hline Product concentration $(\boldsymbol{\mu g} / \mathbf{m l})$ & AUC \\
\hline $10 \mu \mathrm{g} / \mathrm{ml}$ & 400387 \\
\hline $20 \mu \mathrm{g} / \mathrm{ml}$ & 754642 \\
\hline $30 \mu \mathrm{g} / \mathrm{ml}$ & 1121634 \\
\hline $40 \mu \mathrm{g} / \mathrm{ml}$ & 1378482 \\
\hline $50 \mu \mathrm{g} / \mathrm{ml}$ & 1877805 \\
\hline
\end{tabular}




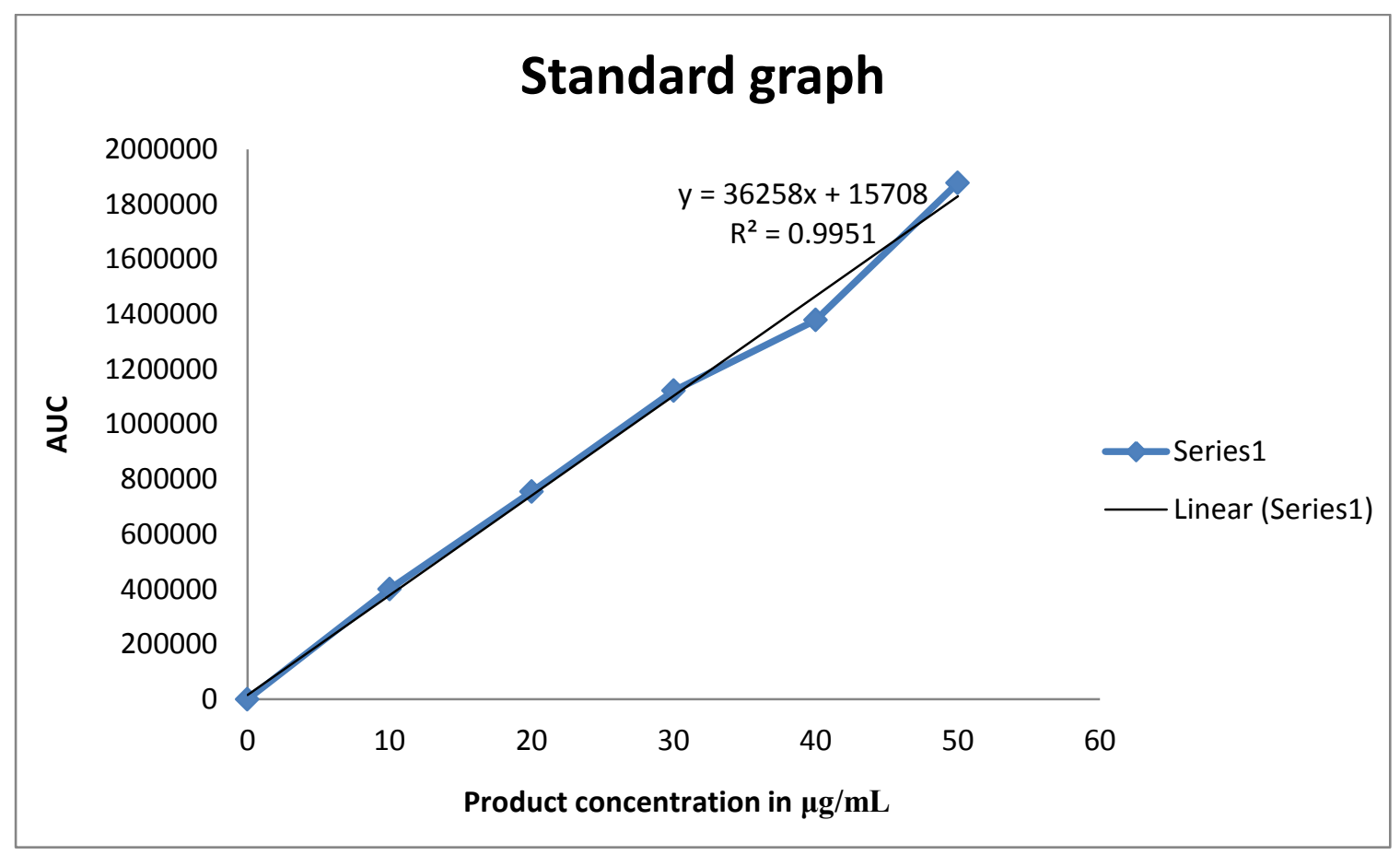

Figure 10. Standard graph of o-hydroxyphenylethanol.

The product concentration was calculated by using the formula:

$y=36258 x+15708$

$x=y-15708 / 36258$

where; $\mathbf{y}$ is AUC and $\mathbf{x}$ is product concentration.

\section{References}

[1] Kaoru N., Rio Y., Tomoko M., Tadao H., Tetrahedron: Asymmetry 14 (2003) 2659-2681.

[2] Hiltrud L., Andreas S., Biotransformations. Biotechnology, 4. http://www.eolss.net/sample-chapters/c17/e6-58-04-06.pdf

[3] Elżbieta P., Dorota Ż., Department of Technology and Biotechnology of Drugs 77 (2009) 9-17.

[4] Magdi A. M. Y, Francis F. H, Moustafa A., Mohamed S., J. Agric. \& Environ. Sci. 7 (2010) 31-37.

[5] Hanan M., Elrashied E., Trends in Applied Sciences Research 6 (2011) 121-129.

[6] Brahmani Priyadarshini S. R, Gopal M., Sandhyavali M. S., International Journal of Pharmaceutical, Chemical and Biological Sciences 2(3) (2012) 236-241.

[7] Aguilar-Uscanga B., Francois J. M., Letters in Applied Microbiology 37 (2003) 268-274. 
[8] Xiao-Hong C., Wen-Yong L., Min-Hua Z., Thomas J. S., BMC Biotechnology 11 (2011) 110.

[9] Chiu-yeh W., Zeng-chin L., Shiu-hsiung W., Journal of Food and Drug Analysis 16(2) (2008) 61-67.

[10] Kyoungkeun Y., Keiko S., Naoki H., Masami T., Tsuyoshi H., Materials Transactions 5(7) (2004) 2429-34.

[11] Neelakantam V. N., Ronan P., Applied And Environmental Microbiology 71 (2005) 2239-2243.

[12] Sivakumar T., Sivasankara N., Shankar T., Vijayabaskar P., International Journal of Applied Biology And Pharmaceutical Technology 3 (2012) 133-143.

[13] Sukumar M., African Journal of Environmental Science and Technology 4(7) (2010) 412-418.

[14] Zi-Jun X., Min-Hua Z., Wen-Yong L., Bioresource Technology 100 (2009) 5560-5565.

[15] Augusto J., Moran S., and Conceicao A., Food Technol. Biotechnol. 42 (2004) 295-303.

[16] Hiromichi O., Toshikuni T., Takeshi S., Tetrahedron: Asymmetry 12 (2001) 2543-2555.

[17] Adi W., Nisim H., Chrstina D., Dorith T., Yoram S., Org. Commun. 1 (2008) 9-16.

[18] Zhong-Hua Y., Xu C., Xuan-Ke L., Guang-Hui, Wand Rong Z., Food Technol. Biotechnol. 46(3) (2008) 322-327.

[19] S. R. Brahman, M. S. Sandhyavali, Gopal M., International journal of pharmaceutical, chemical and biological sciences 2(3) (2012) 236-241.

[20] Yang G., Shanjing Z., and Jiangyan Xu, Journal of Molecular Catalysis B: Enzymatic 57 (2009) 83-88.

[21] Zhang J., Gao N., J. Zhejiang Univ. Sci. B 8 (2007) 98-104.

[22] Chanakya P., Srikanth M., Subba R. S., International Journal of Applied Biology and Pharmaceutical Technology 1 (2010) 1168-74.

[23] Rekha K., Saran S., Jasmine I., Saxena S. K., Journal of Molecular Catalysis B: Enzymatic 40 (2006) 121-26.

[24] Vahap Y., Aktas N., Journal of Molecular Catalysis B: Enzymatic 43 (2006) 9-14.

[25] Vijayalakshmi and Shobha, European food research and tech. 3 (2011) 234-239. 